\title{
Multiplication of contaminant bacteria in urine and interpretation of delayed culture
}

\author{
D. B. WHELDON AND MARY SLACK
}

From the Bacteriology Department and Regional Public Health Laboratory, The Radcliffe Infirmary, Oxford

SUMMARY A prospective study of the bacterial populations of non-infected urine was mounted in an attempt to define the length of delay between voiding and analysis during which culture would not give false positive results due to the multiplication of contaminant bacteria present at the time of voiding.

The findings suggest that culture of urine within four hours of voiding is likely to give a true indication of the presence or absence of infection. With further delay the interpretation of a heavy growth of bacteria in urine becomes progressively more unreliable, even if that growth is in pure culture.

Infection of the urinary tract usually gives bacterial counts in excess of $10^{5}$ organisms per $\mathrm{ml}$ of urine, whereas contaminant bacteria should number less than $10^{4}$ per $\mathrm{ml}$ where good collection methods have been employed (Kass, 1956). These values have been defined for urine cultured soon after voiding, and the extent to which they are applicable to delayed culture has not been made clear. Although there have been many recommendations suggesting the length of time after voiding during which culture may be expected to reflect the original bacterial population of urine (Kass, 1956; Brumfitt et al., 1973; Shrestha, 1975), there appears to be little quantitative work defining these times.

Urine has long been known to be a medium capable of supporting the growth of microorganisms (Pasteur, 1863). Common urinary pathogens have been shown to multiply in urine at about the same rate as in nutrient broth (O'Grady and Cattell, 1966), to reach numbers similar to bacterial numbers found in infection of the urinary tract (Kass, 1956).

The present study has quantitatively investigated the multiplication of contaminant bacteria in urine and has attempted to define the duration of delay during which bacterial culture can be expected to give a reliable indication of the presence or absence of urinary infection.

\section{Material and methods}

Specimens of urine were collected from 106 subjects

Received for publication 1 December 1976 who were asked to pass the first part of the stream into a sterile container. Preparatory washing was not carried out. Specimens were obtained from patients attending a health centre and from members of the hospital staff. Individuals with known diabetes, frank glycosuria, or known urinary tract abnormalities were excluded, as were those receiving antimicrobial therapy.

Cultures were first performed within an hour of voiding, and successive cultures were carried out at $2,4,8,12$, and 24 hours after voiding. Throughout the period of sampling the specimens were kept at a temperature of $19^{\circ} \mathrm{C}-23^{\circ} \mathrm{C}$ (measured ambient room temperature).

Quantitative cultures were carried out using a 10-fold serial dilution technique on solid media. Differential counts of surface colonies were made from blood agar, MacConkey agar being used as an aid to differentiation. In the final sampling, blood agar incorporating $10 \mu \mathrm{g}$ nalidixic acid per $\mathrm{ml}$ was used in parallel with the other two media to allow small numbers of Gram-positive organisms to be counted in the presence of overgrowing enterobacteria. Plates were incubated aerobically for 18 hours at $37^{\circ} \mathrm{C}$. Bacterial counts were obtained from blood agar plates only. Organisms were identified by colonial appearance, microscopical morphology, biochemical characteristics, and, in the case of streptococci, by Lancefield grouping. Glucose and protein estimates were carried out on each urine shortly after voiding, and pus, red and epithelial cell counts were obtained using a modified Fuchs Rosenthal counting chamber. 
Growth curves were constructed for each organism which persisted or multiplied in urine, and from these the time at which any organism was present in counts exceeding $10^{5}$ per $\mathrm{ml}$ was determined.

\section{Definitions}

It was frequently found that two organisms multiplied at similar rates in a single urine specimen, and that both achieved counts in excess of $10^{5}$ per $\mathrm{ml}$ within 24 hours of voiding. In this study the term 'a heavy mixed growth' is used to describe the bacterial population of a specimen in which each strain was present in numbers exceeding $10^{5}$ per $\mathrm{ml}$ and where there was less than a factor of 10 between the counts of the two strains. The term 'a predominant growth' is used to describe any organism with a count in excess of $10^{5}$ per $\mathrm{ml}$ and where there was a difference of a factor of 10 or more between the count of that strain and the count of any other organism present. Such a predominant growth could have been incorrectly interpreted as a pure growth when cultured by semi-quantitative methods in routine use, particularly when present in counts of about $10^{5}$ per $\mathrm{ml}$.

\section{Results}

ORGANISMS PRESENT IN FRESHLY VOIDED URINE

The table summarises the findings at initial sampling. Staphylococci predominated among contaminant organisms, while Escherichia coli, the organism most frequently implicated in urinary tract infection, was not common as a contaminant in numbers exceeding $10^{2}$ per $\mathrm{ml}$.

Fourteen of 41 urines from males $(34 \%)$ and 5 of 65 from females $(7 \cdot 7 \%)$ had bacterial populations of less than $10^{2}$ per $\mathrm{ml}$. None of the urines from males had bacterial counts in excess of $10^{5}$ per $\mathrm{ml}$, whereas four urines from females $(6.2 \%)$ had counts exceed- ing this figure. Of these four, three were found to have heavy growths typical of vaginal contamination, whereas the fourth was found to have a predominant growth of Esch. coli exceeding $10^{7}$ per $\mathrm{ml}$. This specimen, with significant bacteriuria, was excluded from the study.

\section{MULTIPLICATION OF CONTAMINANT}

BACTERIA IN URINE

Enterococci, Esch. coli, coagulase-negative staphylococci (Staphylococcus albus and micrococci), and group B streptococci were the organisms which most commonly multiplied in urine to give counts in excess of $10^{5}$ per $\mathrm{ml}$ within 24 hours of voiding. Figure 1 shows the numbers of isolates of enterococci, Esch. coli, and staphylococci exceeding $10^{5}$ per $\mathrm{ml}$ for each hourly period of delay after voiding.

The growth curves of most of the Esch. coli isolates showed logarithmic growth almost from the time of voiding. The lag phase was usually short and was frequently indetectable by our methods. Enterobacteria other than Esch. coli were rarely isolated in numbers exceeding $10^{2}$ per $\mathrm{ml}$ when sampling was carried out within an hour of voiding but at later samplings showed growth patterns similar to Esch. coli.

Many of the enterococcal isolates also showed logarithmic growth. Because these organisms were isolated more frequently and in higher counts at the first sampling than Esch. coli, they tended to reach counts in excess of $10^{5}$ per ml earlier than the latter. Group B streptococci were found to have growth patterns similar to those of enterococci.

Counts of staphylococci tended to increase more slowly than did the counts of the organisms discussed so far. Many isolates did not multiply, and the majority of those which reached counts in excess of $10^{5}$ per $\mathrm{ml}$ showed a prolonged lag phase before growth became exponential. The growth curves of many staphylococcal isolates actually showed a decrease in colony count during this early period.

Table Counts of organisms isolated at initial sampling of urine

\begin{tabular}{|c|c|c|c|c|c|c|}
\hline \multirow[t]{2}{*}{ Bacterial counts of isolated strains } & \multicolumn{3}{|l|}{ Males } & \multicolumn{3}{|l|}{ Females } \\
\hline & $10^{2}-10^{4}$ & $10^{4}-10^{5}$ & $\begin{array}{l}10^{5} \text { and } \\
\text { above }\end{array}$ & $10^{2}-10^{4}$ & $10^{4}-10^{5}$ & $\begin{array}{l}10^{5} \text { and } \\
\text { above }\end{array}$ \\
\hline Staphylococci [coag-neg, including micrococci] & 20 & 0 & $\mathbf{0}$ & 46 & 11 & 3 \\
\hline [coag-pos] & 3 & 0 & $\mathbf{0}$ & 0 & 0 & 0 \\
\hline Enterococci & 2 & $\mathbf{0}$ & 0 & 17 & 7 & $\mathbf{0}$ \\
\hline Group B streptococci & 3 & $\mathbf{0}$ & 0 & 4 & $\mathbf{0}$ & 0 \\
\hline Esch. coli & 0 & 1 & 0 & 7 & 0 & 1 \\
\hline Proteus mirabilis & 1 & 0 & 0 & 0 & 0 & 0 \\
\hline Other enterobacteria & $\mathbf{0}$ & 0 & $\mathbf{0}$ & 1 & 0 & 0 \\
\hline Corynebacteria & 2 & 0 & 0 & 11 & 4 & 2 \\
\hline a haemolytic streptococci & 8 & $\mathbf{0}$ & $\mathbf{0}$ & 2 & 0 & $\mathbf{0}$ \\
\hline
\end{tabular}




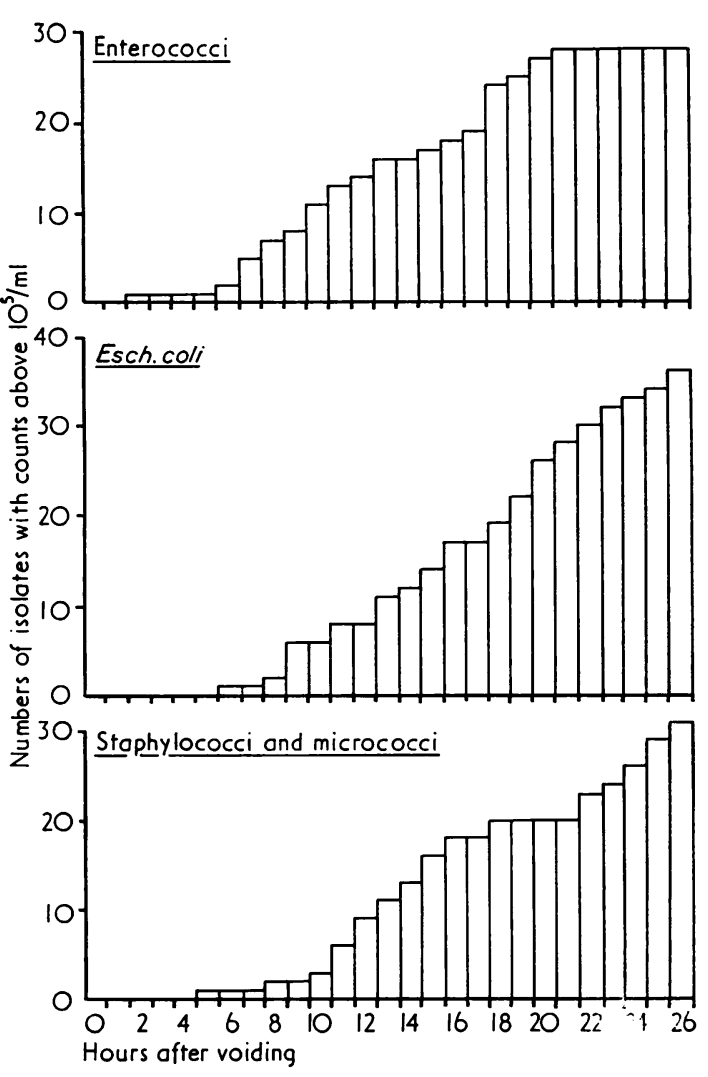

Fig. 1 Incidence of bacterial isolates with counts above $10^{5} / \mathrm{ml}$

Because of apparent slow growth and prolonged lag phase, staphylococci achieved counts in excess of $10^{5}$ per ml later than did enterococci and Esch. coli despite the fact that staphylococci were the organisms found most commonly and in the highest counts as contaminants at the initial sampling.

Growth curves of three isolates representative of their species are shown in Figure 2.

\section{RESULTS OF OVERGROWTH}

The proportions of specimens from each sex giving bacterial growths in excess of $10^{5}$ per $\mathrm{ml}$, and the proportions from each sex giving predominant single-organism growths (as already defined) for each hourly period of delay, are given in Figure 3.

Within the first four hours of delay after voiding only one specimen was found to have a count in excess of $10^{5}$ per $\mathrm{ml}$ due to the multiplication of contaminant bacteria. However, after four hours there was a marked correlation between hours of further delay and the numbers of specimens with heavy bacterial growths.

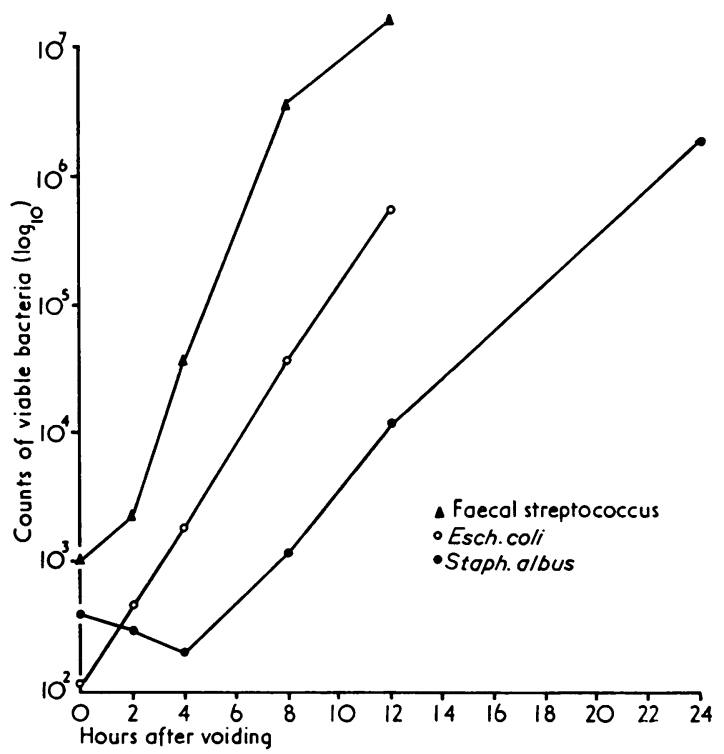

Fig. 2 Growth curves of three representative contaminant organisms

As already indicated, the relative importance of different species causing predominant growths was found to vary with the duration of delay after voiding. Figure 4 shows the incidence of predominant growths. Predominant growths due to the multiplication of enterococci tended to occur before 12 bours, whereas Esch. coli in predominant growth was uncommon before 8 hours but increased after this time.

The changing bacterial populations sometimes resulted in a different distribution of predominant organisms in a single specimen during the 24 hours of study: the transient drop in numbers of predominant growths at 14 hours for specimens from males and at 16 hours for specimens from females shown in Fig. 2 is due to the collective result of the altering distributions of predominant organisms. At these times the numbers of heavy mixed growths were proportionately increased.

\section{DECLINE OF BACTERIAL NUMBERS IN URINE}

The transient fall in counts of staphylococcal isolates before the phase of logarithmic growth has been mentioned. Apart from this the only other organisms showing consistent decline in numbers were corynebacteria. Isolates of Esch. coli were rarely found to decrease in numbers.

\section{Discussion}

Our findings suggest that culture of urine within 4 

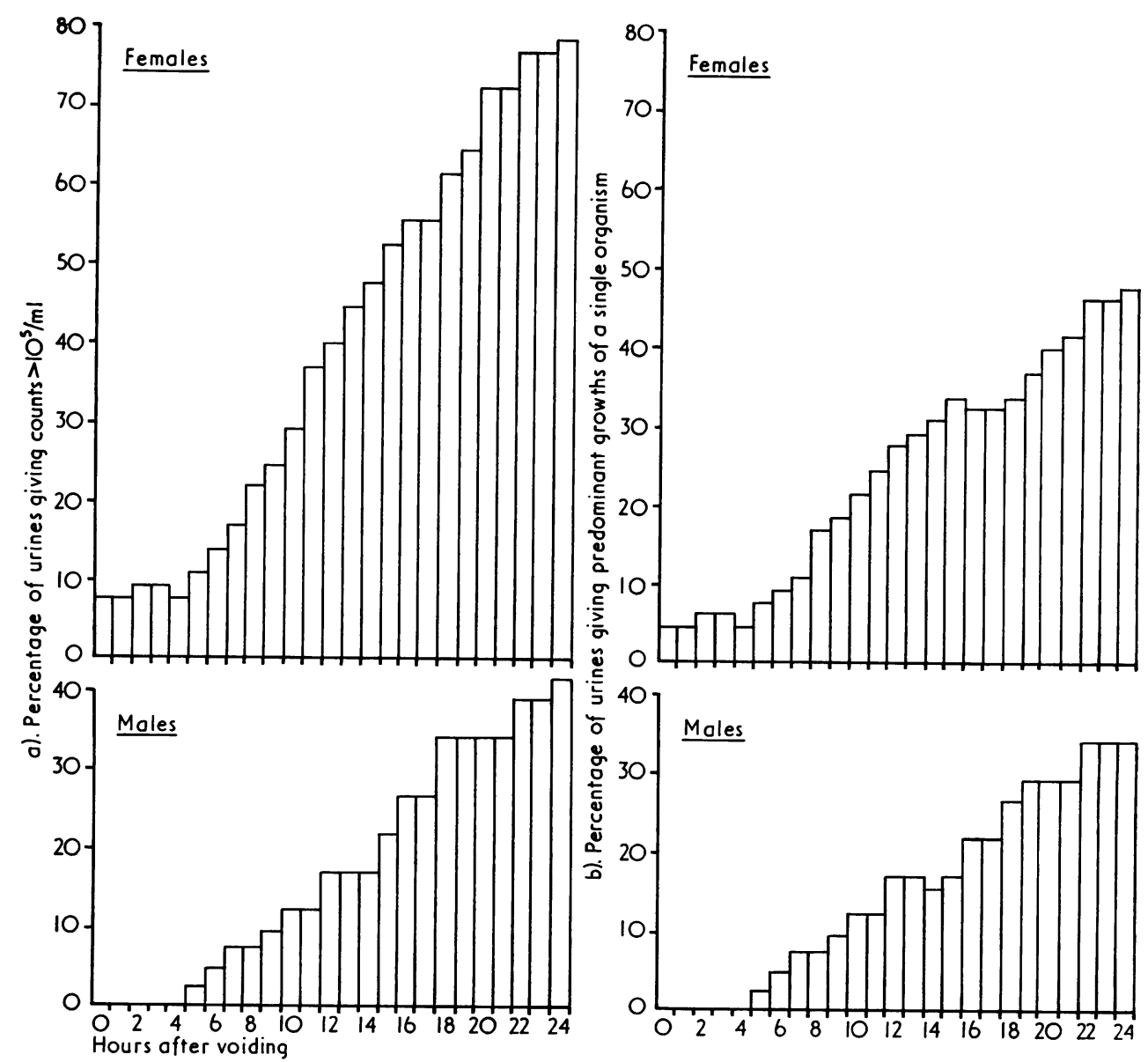

Fig. 3

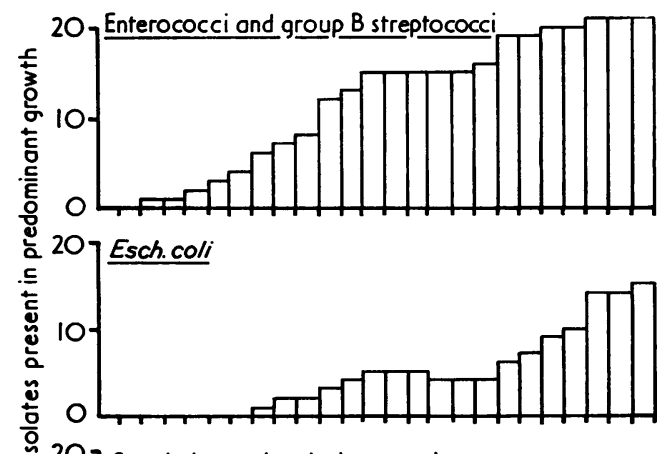

Fig. 3 Percentages of urine specimens giving (a) growths above $10^{5} / \mathrm{ml}$, and (b) predominant growths of a single organism (as defined in text)

Fig. 4 Incidence of organisms present in predominant growth

Fig. 4

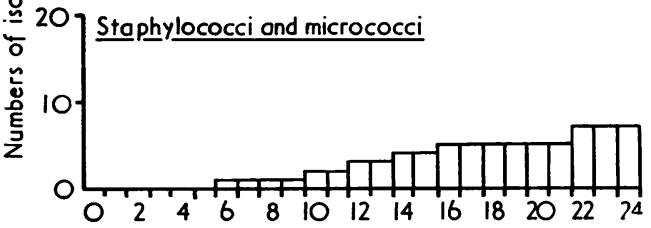


hours of voiding may be expected to reflect the bacterial population present at the time of voiding. Delay in excess of 4 hours before culture resulted in the appearance of increasing numbers of heavy growths due to the multiplication of contaminant bacteria. The finding that Esch. coli did not commonly occur in non-infected urine in numbers greater than $10^{5}$ per $\mathrm{ml}$ within 8 hours of voiding is noteworthy and suggests that predominant growths of this organism found in urine specimens where culture has been delayed up to this time are likely to indicate the presence of infection. Similarly, the finding that enterococci were responsible for the majority of predominant growths in delayed specimens indicates that heavy growths of these organisms should be regarded with particular suspicion when occurring in old or untimed specimens. Urinary tract infections caused by enterococci and group B streptococci are not common but may be associated with abnormalities of the urinary tract (McGeachie, 1966; Mhalu, 1976). For these reasons it appears to be particularly important that the significance of heavy growths of these organisms occurring in old or untimed specimens should be verified by the repeat culture of a fresh specimen. Urinary leucocyte counts may be of limited value in the diagnosis of urinary infection caused by enterococci, as infection due to these organisms is particularly likely to be unaccompanied by pyuria (Rhoads et al., 1952).

While our findings indicate that delay of up to 4 hours at room temperature before culture may be of little importance in the interpretation of the results of bacterial analysis of urine, rapid transport of specimens to the laboratory is desirable as casts may quickly disintegrate after voiding. White cells, too, may perish rapidly under adverse conditions (Triger and Smith, 1966).
The major implication of this study is that culture should be performed on urine within 4 hours of voiding. Where this is impossible the adoption of refrigeration or preservation of specimens should be considered.

We thank Dr. D. C. Turk and Dr. H. H. Johnston for advice during the course of this study, Mr. M. Crow for the determination of cell counts on the specimens, and Mr. C. Saunders for carrying out Lancefield grouping on the streptococcal isolates.

\section{References}

Brumfitt, W., Percival, A., and Williams, J. D. (1973) Estimation of bacteria and white cells in the urine. Ass. clin. Path., Broadsheets, 80.

Kass, E. H. (1956). Asymptomatic infections of the urinary tract. Trans. Ass Amer Phycns, 69, 56-64

McGeachie, J. (1966). Quantitative bacteriology of urinary infection. Brit. J. Urol., 38, 294-301.

Mhalu, F. S. (1976). Infection with Streptococcus agalactiae in a London hospital. J. clin. Path., 29, 309-312.

O'Grady, F. and Cattell, W. R. (1966). Kinetics of urinary tract infection. Brit. J. Urol., 38, 149-162.

Pasteur, L. (1863). Examen du rôle attribué au gaz oxygène atmosphérique dans la destruction des matières animales et végétales après la mort. C.R. Acad. Sci. (Paris), 56, 734-740.

Rhoads, P. S., Billings, C. E., and O'Conor, V. J. (1952). Antibacterial management of urinary tract infections. J. Amer. med. Ass., 148, 165-170.

Shrestha, T. L. (1975). Effects of delayed culture on semiquantitative urinary bacteriology results. J. clin. Path., 28, 392-393.

Triger, D. R. and Smith, J. W. G (1966). Survival of urinary leucocytes. J. clin. Path., 19, 443-447. 